\title{
Degeneration of Dopaminergic Neurons Due to Metabolic Alterations and Parkinson's Disease
}

\author{
Juhyun Song and Jongpil Kim* \\ Department of Biomedical Engineering, Dongguk University, Seoul, South Korea
}

The rates of metabolic diseases, such as type 2 diabetes mellitus (T2DM), obesity, and cardiovascular disease (CVD), markedly increase with age. In recent years, studies have reported an association between metabolic changes and various pathophysiological mechanisms in the central nervous system (CNS) in patients with metabolic diseases. Oxidative stress and hyperglycemia in metabolic diseases lead to adverse neurophysiological phenomena, including neuronal loss, synaptic dysfunction, and improper insulin signaling, resulting in Parkinson's disease (PD). In addition, several lines of evidence suggest that alterations of CNS environments by metabolic changes influence the dopamine neuronal loss, eventually affecting the pathogenesis of PD. Thus, we reviewed recent findings relating to degeneration of dopaminergic neurons during metabolic diseases. We highlight the fact that using a metabolic approach to manipulate degeneration of dopaminergic neurons can serve as a therapeutic strategy to attenuate pathology of PD.

OPEN ACCESS

Edited by:

Antonio Camins,

University of Barcelona, Spain

Reviewed by: Daniel Ortuño-Sahagún, Centro Universitario de Ciencias de la Salud, Mexico Jordi Olloquequi, Universidad Autónoma de Chile,

Chile

${ }^{*}$ Correspondence: Jongpil Kim jk2316@gmail.com; jpkim153@dongguk.edu

Received: 10 February 2016 Accepted: 17 March 2016

Published: 30 March 2016

Citation:

Song J and Kim J (2016) Degeneration of Dopaminergic Neurons Due to Metabolic Alterations and Parkinson's Disease. Front. Aging Neurosci. 8:65. doi: 10.3389/fnagi.2016.00065
Keywords: dopaminergic neurons, metabolic diseases, aging, neurodegenerative diseases, Parkinson's disease (PD)

\section{INTRODUCTION}

Changing lifestyles means that many older people suffer from metabolic syndromes, including type 2 diabetes (T2DM), obesity, and cardiovascular disease (CVD; Luchsinger, 2010). Aging is accompanied by a variety of physiological changes, such as mitochondrial dysfunction, inflammation and a decline in insulin sensitivity (Dillin et al., 2002; Lee et al., 2003; Short et al., 2005; Riera and Dillin, 2015), which finally lead to age-related diseases. According to a recent survey, the prevalence of metabolic diseases increases by approximately $46.7 \%$ among people older than 60 years compared to younger individuals (Sepúlveda and Murray, 2014). Furthermore, this prevalence increases by over 50\% in people aged over 65 years (Aguilar et al., 2015). Consequently, as the global population ages there will be a higher prevalence of CVD, T2DM and obesity (Kalyani et al., 2014; Sepúlveda and Murray, 2014; Hinnouho et al., 2015). Moreover, several studies have found that metabolic diseases are significantly linked to neurodegenerative diseases such as Alzheimer's disease (AD) and Parkinson's disease (PD; Anthony et al., 2006; Tezapsidis et al., 2009; Ahtiluoto et al., 2010; Lara et al., 2013; Ninomiya, 2014). Patients with neurodegenerative diseases like PD commonly suffer motor disturbance due to the degeneration or loss of dopaminergic neurons (Michel et al., 2013; Kalia and Lang, 2015). In fact, one clinical research study demonstrated that dopaminergic neuron activity strongly influences metabolic alterations in humans (Brunerova et al., 2013). Thus, the loss of dopaminergic neurons and degeneration 
should be an area of research focus to identify a therapeutic solution for metabolic change-induced PD. Here, we review recent studies and provide new insight on the link between metabolic diseases and the degeneration of dopaminergic neurons, which consequently leads to PD.

\section{THE ASSOCIATION BETWEEN METABOLIC DISEASES AND PD}

Among metabolic disorders, T2DM is associated with neurodegenerative diseases, including diabetic neuropathy and Alzheimer's disease (Wild et al., 2004; Boulton et al., 2005). In addition, recent studies reported a positive correlation between diabetes and dementia risk (Cheng et al., 2012; Gudala et al., 2013; Vagelatos and Eslick, 2013). According to many epidemiological studies, the impairment of insulin action in people with T2DM, could lead to brain dysfunction (Boulton et al., 2005; Corti et al., 2011), such as cognitive decline, compared to people not suffering from the disorder ( $\mathrm{Lu}$ and $\mathrm{Hu}, 2012$ ). In particular, insulin resistance is thought to promote chronic hyperglycemia (Ahtiluoto et al., 2010), and leads to cognitive impairment and vascular dementia by promoting the secretion of proinflammatory cytokines (Ninomiya, 2014). Decreased insulin receptors in the PD brain is related to neuronal loss in the substantia nigra (Moroo et al., 1994). In fact, one clinical study suggested that diabetes results in Parkinsonian signs such as postural reflex and gait impairment (Arvanitakis et al., 2007). Furthermore, obesity is considered the main cause of hypothalamic inflammation (Tang et al., 2015). Excessive fat accumulation induces inflammatory responses by promoting proinflammatory cytokine production in the central nervous system (CNS; Velloso et al., 2015). There is a strong relationship between high levels of adipokines, generated by adipose tissues (Buchman et al., 2005), and cognitive decline, and the former can be used as a predictor of the latter (Zeki Al Hazzouri et al., 2013). Some studies indicated a remarkable effect of leptin, as an adipokine, on memory loss in obese animal models (Bigalke et al., 2011; Theodoropoulou et al., 2012). Another study demonstrated that leptin improves cognitive function in mice that showed motor dysfunction and memory decline (Farr et al., 2006). Furthermore, clinical studies report that patients with metabolic disorder also show decreased cognitive function (Vieira et al., 2011; Levin et al., 2014). Studies on PD show significantly decreased heart function in patients (Rodríguez et al., 1996; Kallio et al., 2000). The association between cardiovascular autonomic dysfunction and PD has been further highlighted by recent evidence (Cilia et al., 2015). Also, high blood pressure considered an important risk factor in CVD increases the prevalence of dementia (Qiu et al., 2005). Many evidences indicate that hypertension and blood pressure are strongly associated with neurotoxicity in the brain (Langbaum et al., 2012; Toledo et al., 2012; Rodrigue et al., 2013). Taken together, metabolic diseases including T2DM, obesity, and CVD are linked to the onset and development of PD. Considering connected consequences between these disorders, we suggest that investigation for common issues need to improve multiple pathologies in metabolic changeinduced PD.

\section{DEGENERATION OF DOPAMINERGIC NEURONS AND PD}

Dopamine is primarily regarded as a neurotransmitter that controls the brain reward system (Blum et al., 2000). Midbrain dopaminergic neurons in brain areas, such as the substantia nigra pars compacta, regulate movement activation and cognitive functions by binding dopamine D1 and D2 receptors (Palmiter, 2007, 2008; Kravitz et al., 2010; Tritsch and Sabatini, 2012; Calabresi et al., 2014). In vivo pharmacological studies have suggested that the blockade of dopamine receptors in the dorsolateral prefrontal cortex and dorsal striatum, reduces cognitive functions (Landau et al., 2009; Cools, 2011; Li and Mei, 1994; Sawaguchi and Goldman-Rakic, 1994). Loss of dopaminergic neurons triggers a deregulation of motor symptoms such as rigidity and postural instability (RodriguezOroz et al., 2009; Masoud et al., 2015). PD is characterized by the progressive loss of dopaminergic neurons of the substantia nigra pars compacta that project to the striatum (Michel et al., 2013; Kalia and Lang, 2015). Imaging studies in PD patients have reported a positive correlation between cognitive deficits, and the reduction of dopamine levels in the frontostriatal circuit (Brück et al., 2001, 2005; Sawamoto et al., 2008; Jokinen et al., 2009). Postmortem studies in PD patients have shown the loss of cholinergic (Zweig et al., 1989), and dopaminergic neurons (Karachi et al., 2010) which are crucial in the progression of PD. Moreover, one study found that cognitive decline in $\mathrm{PD}$ is strongly associated with the disruption of dopamine signaling in the prefrontal cortex (Narayanan et al., 2013). The pathology of PD is strongly linked to the death of dopaminergic neurons and the presence of Lewy bodies (Chase et al., 1998). Another study also reported a relationship between dopamine neuron degeneration and cognitive impairments (Bromberg-Martin et al., 2010). The intracellular mechanisms of dopaminergic neurons, and the environmental conditions around them, contribute to the progress of familial and sporadic PD forms (Dauer and Przedborski, 2003; Rodriguez et al., 2014; Ryan et al., 2015). The cellular mechanisms related to dopaminergic neuron degeneration are associated with increased sensitivity to mitochondrial dysfunction (Jeon et al., 1995; Lotharius et al., 1999; Kann and Kovács, 2007) and changes in protein degradation (Mosharov et al., 2009; Yacoubian and Standaert, 2009; Dehay et al., 2015). These researches indicated that the change of mitochondria energy metabolism caused by metabolic changes influences the expression of PD related proteins such as LRRK2, $\alpha$-Syn, PINK-1, UCHL1, DJ-1. Recent studies found a number of causes for dopaminergic neuron degeneration such as oxidative stress (Segura-Aguilar et al., 2014), aging (Ba and Martin, 2015) and neuroinflammation (Ryan et al., 2015). Based on these studies, decreased dopamine transporters in dopaminergic neuron could be used as the indicator to diagnose PD, in that the level of dopamine decisively affects the pathology progress of PD. The damage to dopaminergic neurons is mediated by the 
apoptosis signal, p53, which was found using an in vitro PD model (Li et al., 2016). Based on previous evidence, the degeneration of dopaminergic neurons is an important issue in the progression of $\mathrm{PD}$, and its mechanisms should be studied to identify therapeutic solutions using a variety of approaches.

\section{DEGENERATION OF DOPAMINERGIC NEURONS DURING T2DM}

\section{Insulin Resistance and Dopaminergic Neurons}

The brain, as an energy expensive organ, consumes 20\% of the oxygen and glucose in the body (Zlokovic, 2011). Insulin interacts with the blood brain barrier (BBB) to initiate signaling pathways within the brain (Kastin and Akerstrom, 2001; Kondo et al., 2004; Ueki et al., 2004; Banks et al., 2012). Appropriate insulin levels are necessary to maintain sufficient glucose transport to the brain (Reagan et al., 2001; Bingham et al., 2002; McNay et al., 2010). Insulin action in the brain has been reported to modulate neuronal survival, synaptic function, cognitive function and neuronal circuit formation (Cholerton et al., 2011; Banks et al., 2012). The hormone inhibits neuronal damage resulting from glucose-oxygen deprivation (Sun et al., 2010), excitotoxicity (Kim and Han, 2005) and oxidative stress (Ribeiro et al., 2014). Insulin receptors have been found in midbrain dopaminergic neurons (Figlewicz et al., 2003). It increases dopaminergic transporter activity and enhances the clearance of dopamine from the synapse (Davis et al., 2011). Insulin action influences the function of the dopamine transporter, which is a key regulator of dopamine neurotransmission (Speed et al., 2011) and is important for cognitive ability (Figlewicz and Benoit, 2009; Figlewicz and Sipols, 2010). In addition, insulin signaling in dopaminergic neurons plays a crucial role in energy balance and the reward system (Khanh et al., 2014). Impaired insulin signaling aggravates brain dysfunction related to dopamine homeostasis (Carvelli et al., 2002; Garcia et al., 2005; Owens et al., 2005; Wei et al., 2007). Previous researches demonstrated that brain insulin resistance controls both the reward system and dopamine system (Luo et al., 1999; Anthony et al., 2006). Moreover, insulin-like growth factor (IGF-1) receptors within the substantia nigra (Dunn and Castro, 1980), induce insulin signaling and stimulate the activation of the phosphatidylinositol 3-kinase/AKT/glycogen synthase kinase-3 beta and mitogen-activated protein kinase pathways (Avila-Gomez et al., 2010) that modulate cell survival. Several studies indicated that IGF-1 receptors could rescue dopaminergic neurons from apoptosis (Cheng et al., 2011; Zawada et al., 1996; Wang et al., 2010). Akt signaling related to insulin signaling (Hage Hassan et al., 2015; Sadi et al., 2015; $\mathrm{Xu}$ et al., 2015) is markedly associated with the regulation of dopaminergic signaling (Beaulieu et al., 2007, 2009) and dopaminergic homeostasis (Hanada et al., 2004; Garcia et al., 2005; Williams et al., 2007). Notably, clinical research studies reported that a human genetic variant of the Akt insulin signaling pathway, found in patients, dysregulated the dopamine system
(Emamian et al., 2004; Ikeda et al., 2006). In in vivo studies, genetic modification of Akt results in the dysregulation of dopaminergic neuron homeostasis (Siuta et al., 2010). Another study showed that a decrease in plasma insulin levels in rats, results in impaired insulin action on dopaminergic neurons (Patterson et al., 1998). Also, the ablation of insulin receptors in dopaminergic neurons leads to intercellular damage to the neurons (Könner et al., 2011), while insulin administration to rats showed an increase in dopamine transporter protein (Figlewicz et al., 1994). Moreover, insulin resistance in the brain changes dopamine turnover and results in movement disorders (Kleinridders et al., 2015). Insulin resistance caused by a high-fat diet exacerbates dopaminergic degeneration in mice (Bousquet et al., 2012). Clinical studies found increased insulin resistance and decreased insulin concentrations in the cerebrospinal fluid of patients with neurodegenerative disorders (Bomfim et al., 2012; Talbot et al., 2012). Some surveys reported an increased PD risk in patients with T2DM, accompanied by insulin resistance (Hu et al., 2007; Sun et al., 2012). One study found that Daf-2/Daf-16 insulin-like signaling pathway is important in mechanisms connecting $\mathrm{PD}$ and diabetes such as alpha-synuclein pathology of PD under high glucose conditions (Fatima et al., 2014). Recent research, using in vitro and in vivo models, demonstrated that appropriate insulin levels could protect dopaminergic neuronal damage in the substantia nigra during PD (Pang et al., 2016). Recently, drugs to treat insulin resistance demonstrated protective effects in PD (AvilesOlmos et al., 2013a,b). Overall, the role of insulin signaling on dopaminergic neurons in $\mathrm{PD}$, in a background of T2DMrelated insulin resistance, should be investigated to understand the underlying mechanisms.

\section{Inflammation Caused by Hyperglycemia and Dopaminergic Neurons}

Several studies suggest that neuronal loss in PD is associated with chronic neuroinflammation related to microglia and immune cells in the brain (Barcia et al., 2003; Perry, 2012). Clinical studies observed higher levels of pro-inflammatory factors such as interleukin (IL)-1beta, IL-2, tumor necrosis factor (TNF)-alpha, interferon (IFN)-gamma, and cluster of differentiation (CD)4+ and CD8+ T lymphocytes in PD brains (Dobbs et al., 1999; Hisanaga et al., 2001; Reale et al., 2009). Microglial activation in the substantia nigra (Lawson et al., 1990) was commonly observed in PD patients (Doorn et al., 2014a), and in PD animal models (Doorn et al., 2014b; Pisanu et al., 2014; Stott and Barker, 2014). In oxidative stress caused by PD, microglia promote an inflammatory state contributing to dopaminergic neuronal degeneration (McGeer and McGeer, 2008; FrankCannon et al., 2009; Burbulla et al., 2010). According to these evidences, the activation of M2 type microglia which secrets anti-inflammatory cytokines such as transforming growth factor (TGF)-beta and IL-10 improves the pathology of PD. The production of pro-inflammatory cytokines by inflammation leads to the apoptosis of dopaminergic neuron. Impaired glucose tolerance was observed in $80 \%$ of PD cases (Sandyk, 1993; Hu et al., 2007). The high glucose condition in T2DM triggers 
oxidative stress and dopaminergic neuronal death (Giaccari et al., 2009; Zhang et al., 2011; Renaud et al., 2014; Yoon and Oh, 2015). Dopaminergic neurons in the brain deteriorate due to increased production of reactive oxygen species (ROS) under high glucose stress (Pearce et al., 1997; Brownlee, 2001; Cui et al., 2012). These researches indicated that insulin level and glucose dysregulation could influence dopaminergic neuron's degeneration. Clinical research found that dopaminergic neurons were damaged through apoptosis signaling pathways, such as p53 (Tatton, 2000; Hartmann and Hirsch, 2001; Nair, 2006), in PD patients, and an increase in activated microglia was observed in the basal ganglia of PD patients (Ouchi et al., 2005). One study found that long term incubation under high glucose concentrations increased depolarization-induced dopamine release (Koshimura et al., 2003). In addition, studies also found a correlation between blood glucose levels and cerebrospinal fluid concentrations of dopamine metabolites (Umhau et al., 2003). Detrimental inflammatory conditions, resulting from high glucose concentrations, have been reported to induce degeneration and cell death of dopaminergic neurons in PD animal models (Hu et al., 2007; Cai, 2009; Morris et al., 2010; Machado et al., 2011; Yoon and Oh, 2015). In summary, given that metabolic inflammation exacerbates dopaminergic neuronal damage in response to T2DM (Wang et al., 2014), the inflammatory environment caused by T2DM should be controlled to attenuate dopaminergic neuronal degeneration in PD.

\section{DEGENERATION OF DOPAMINERGIC NEURONS IN OBESITY}

Improper functioning of dopaminergic neurons in obesity is an important issue (Stice et al., 2008). Reduced dopaminergic receptor 2 expression in obesity, has been reported (Stice et al., 2008, 2010). Another study found low expression levels of dopaminergic receptor 2 in obese subjects compared to nonobese controls (Wang et al., 2011). Dopamine D2 receptor in the striatum was markedly lower in obese rats compared to lean control rats (Hamdi et al., 1992). Moreover, one study showed that dopamine transporter levels negatively correlated with body mass index (BMI), suggesting that the dopamine system regulates BMI (Chen et al., 2008). Recent studies indicated that the improvement of dopamine function could be key to the treatment of obese subjects (Avena et al., 2013a,b; Blum et al., 2014; Curtis and Davis, 2014). The increase in dopaminergic neuron receptors D1 and D2 reduces body fat, serum levels of free fatty acid, glucose and insulin (Cincotta et al., 1997; Conti et al., 2001). Freeman et al. (2001) investigated the effect of glucose in dopamine neuronal activity and found that a change in activity is influenced by caloric intake. One study demonstrated that the dopamine system is sensitive to alterations in energy metabolism (van der Plasse et al., 2015). Dopaminergic neuron D2 receptor levels are inversely associated with the BMI of obese subjects (Volkow et al., 2009; Michaelides et al., 2012). According to some findings, obesity

\section{Aging}

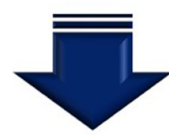

\section{Metabolic changes}

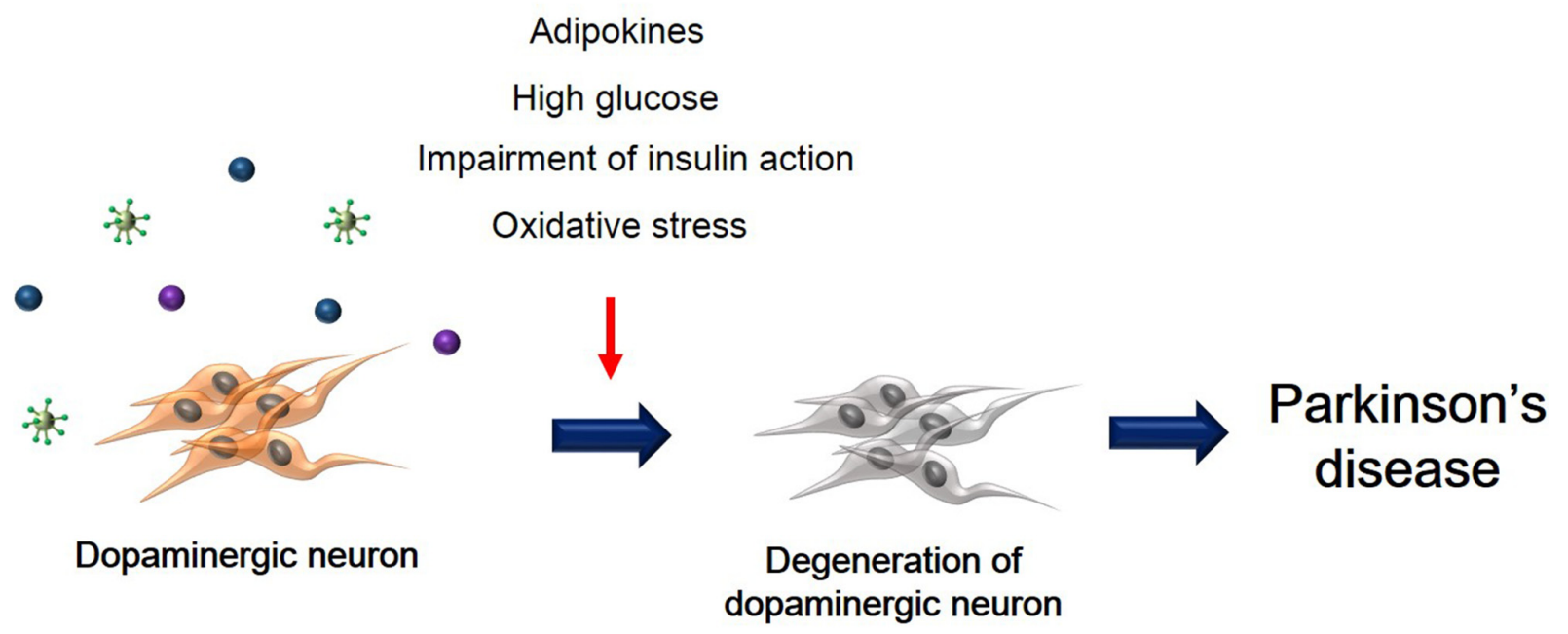

FIGURE 1 | The schematic image regarding dopaminergic neuron's degeneration caused by metabolic changes. This image shows that degeneration of dopaminergic neuron was accelerated by aging-induced metabolic changes including high glucose, insulin action's impairment, oxidative stress, and adipokines. 
associated genes control the activity of midbrain dopaminergic circuitry (Hess et al., 2013). Dopaminergic neurons in the midbrain are reported to play a crucial role in controlling food seeking behavior (Salamone et al., 1997; Roitman et al., 2004; van Zessen et al., 2012), by affecting the metabolic state and some hormones (van Zessen et al., 2012). An in vivo study using leptin-null mice (leptin is a key molecule, which links metabolic information to reward signaling) showed that feeding behavior is influenced by dopamine levels (Szczypka et al., 2000). Recent research found a loss of dopaminergic neurons due to metabolic dysregulation in an animal model of obesity, under a chronic high fat diet (Khang et al., 2015). Therefore, further studies on dopaminergic neuronal degeneration in obesity may be crucial to alleviate obesityinduced neuropathophysiology.

\section{DEGENERATION OF DOPAMINERGIC NEURONS IN CVD}

CVD is generally accompanied by hypertension and atherosclerosis due to the accumulation of atheromatous plaques in coronary arteries, and is one of the main causes of death worldwide (Braunwald, 1997). Some studies show that cardiac failure is involved during the onset and prevalence of PD (Zesiewicz et al., 2004; Ziemssen and Reichmann, 2007, 2010). Based on clinical research, approximately $35 \%$ of $\mathrm{PD}$ patients show cardiac denervations (Goldstein, 2006; Goldstein et al., 2012; Martorell-Riera et al., 2014). Recent results support the relationship between mitofusin 2, as a functional element in heart mitophagy, and PTEN-induced putative kinase 1 (PINK1), as a PD-related factor (Chen and Dorn, 2013). Cardiac sympathetic denervation in $\mathrm{PD}$ is central to understanding the relationship between CVD and dopaminergic neurons (Goldstein et al., 2007). Dopamine plays a beneficial role in hypertension patients (Lyzogub et al., 2014). Low dose dopamine activates dopaminergic receptors, and ameliorates vasodilatation of the coronary and cerebral vessels (Liang et al., 2008; Chen et al., 2013). Cardiac sympathetic denervation is significantly related to the loss of nigrostriatal dopaminergic neurons (Goldstein et al., 2008, 2011, 2012). PD is associated with decreased myocardial innervations and increased cardiac sympathetic denervation (Orimo et al., 2002; Amino et al., 2005). Several studies have reported the presence of the renin angiotensin system (RAS) in basal ganglia, and high concentrations of angiotensin converting enzyme have been found in the striatum and substantia nigra of mammals (Chai et al., 1987; Allen et al., 1992). An interaction between dopaminergic neurons and angiotensin II receptors were demonstrated by several studies

\section{REFERENCES}

Aguilar, M., Bhuket, T., Torres, S., Liu, B., and Wong, R. J. (2015). Prevalence of the metabolic syndrome in the United States, 2003-2012. JAMA 313, 1973-1974. doi: 10.1001/jama.2015.4260

Ahtiluoto, S., Polvikoski, T., Peltonen, M., Solomon, A., Tuomilehto, J., Winblad, B., et al. (2010). Diabetes, Alzheimer disease and vascular dementia: on the regulation of cardiovascular function (Zeng et al., 2006; Khan et al., 2008; Gildea, 2009). Recent findings show abnormal interactions between dopaminergic neurons and angiotensin II, affecting both neurodegenerative diseases and hypertension (Gildea, 2009; Li et al., 2008). Chronic inhibition of RAS leads to increased dopaminergic neuronal function (Jenkins et al., 1997, 1999; Reardon et al., 2000; Villar-Cheda et al., 2010). RAS hyperactivity is related to dopaminergic neuron degeneration in $\mathrm{PD}$, and involves oxidative stress and neuroinflammation (VillarCheda et al., 2010). Collectively, understanding the mechanisms connecting dopaminergic neuron degeneration and CVD, is a fundamental issue to improve PD pathologies, as dopaminergic neurons are involved in heart function by modulating the RAS system and controlling cardiac inflammation.

\section{CONCLUSION}

Metabolic changes due to aging could affect multiple neuropathological mechanisms, and may also contribute to the progression and onset of PD (Figure 1). Insulin resistance and the hyperglycemia condition caused by T2DM lead to damage of dopaminergic neurons via several signaling pathways. In addition, inflammation, adipokine dysfunction and inappropriate energy metabolism by obesity, trigger the loss and degeneration of dopaminergic neurons. Heart failure related to RAS hyperactivity and cardiac inflammation cause the degeneration of dopaminergic neurons. Taken together, metabolic alterations could affect dopaminergic neuronal loss and degeneration, leading to PD neuropathology including motor disturbance and cognitive decline. Hence, we suggest that manipulating dopaminergic neuron degeneration by targeting metabolic pathways propose therapeutic approaches to ameliorate metabolic effects in PD.

\section{AUTHOR CONTRIBUTIONS}

JS wrote the preliminary draft and revised details of the manuscript. JK revised all manuscript in detail.

\section{ACKNOWLEDGMENTS}

This work was supported by the National Research Foundation funded by the Korea government, (NRF-2013R1A1A1058835), (NRF-2013M3A9B4076485), (NRF-2015 M3A9B4051064), Korea Health Technology R\&D Project, Ministry of Health and Welfare (HI13C0540) and the Next-Generation BioGreen 21 Program, Rural Development Administration (PJ 01107701).

a population-based neuropathologic study. Neurology 75, 1195-1202. doi: 10 1212/WNL.0b013e3181f4d7f8

Allen, A. M., MacGregor, D. P., Chai, S. Y., Donnan, G. A., Kaczmarczyk, S., Richardson, K., et al. (1992). Angiotensin II receptor binding associated with nigrostriatal dopaminergic neurons in human basal ganglia. Ann. Neurol. 32, 339-344. doi: 10.1002/ana.4103 20306 
Amino, T., Orimo, S., Itoh, Y., Takahashi, A., Uchihara, T., and Mizusawa, H. (2005). Profound cardiac sympathetic denervation occurs in Parkinson's disease. Brain Pathol. 15, 29-34. doi: 10.1111/j.1750-3639.2005.tb00097.x

Anthony, K., Reed, L. J., Dunn, J. T., Bingham, E., Hopkins, D., Marsden, P. K., et al. (2006). Attenuation of insulin-evoked responses in brain networks controlling appetite and reward in insulin resistance: the cerebral basis for impaired control of food intake in metabolic syndrome? Diabetes 55, 2986-2992. doi: 10.2337/db06-0376

Arvanitakis, Z., Wilson, R. S., Bienias, J. L., and Bennett, D. A. (2007). Diabetes and parkinsonian signs in older persons. Alzheimer Dis. Assoc. Disord. 21, 144-149. doi: 10.1097/wad.0b013e31805ba768

Avena, N. M., Murray, S., and Gold, M. S. (2013a). Comparing the effects of food restriction and overeating on brain reward systems. Exp. Gerontol. 48, 1062-1067. doi: 10.1016/j.exger.2013.03.006

Avena, N. M., Murray, S., and Gold, M. S. (2013b). The next generation of obesity treatments: beyond suppressing appetite. Front. Psychol. 4:721. doi: 10. 3389/fpsyg.2013.00721

Avila-Gomez, I. C., Velez-Pardo, C., and Jimenez-Del-Rio, M. (2010). Effects of insulin-like growth factor-1 on rotenone-induced apoptosis in human lymphocyte cells. Basic Clin. Pharmacol. Toxicol. 106, 53-61. doi: 10.1111/j. 1742-7843.2009.00472.x

Aviles-Olmos, I., Dickson, J., Kefalopoulou, Z., Djamshidian, A., Ell, P., Soderlund, T., et al. (2013a). Exenatide and the treatment of patients with Parkinson's disease. J. Clin. Invest. 123, 2730-2736. doi: 10.1172/JCI68295

Aviles-Olmos, I., Limousin, P., Lees, A., and Foltynie, T. (2013b). Parkinson's disease, insulin resistance and novel agents of neuroprotection. Brain 136, 374-384. doi: 10.1093/brain/aws009

Ba, F., and Martin, W. R. (2015). Dopamine transporter imaging as a diagnostic tool for parkinsonism and related disorders in clinical practice. Parkinsonism Relat. Disord. 21, 87-94. doi: 10.1016/j.parkreldis.2014.11.007

Banks, W. A., Owen, J. B., and Erickson, M. A. (2012). Insulin in the brain: there and back again. Pharmacol. Ther. 136, 82-93. doi: 10.1016/j.pharmthera.2012. 07.006

Barcia, C., Fernández Barreiro, A., Poza, M., and Herrero, M. T. (2003). Parkinson's disease and inflammatory changes. Neurotox. Res. 5, 411-418. doi: 10.1007/BF03033170

Beaulieu, J. M., Gainetdinov, R. R., and Caron, M. G. (2007). The Akt-GSK3 signaling cascade in the actions of dopamine. Trends Pharmacol. Sci. 28, 166-172. doi: 10.1016/j.tips.2007.02.006

Beaulieu, J. M., Gainetdinov, R. R., and Caron, M. G. (2009). Akt/GSK3 signaling in the action of psychotropic drugs. Annu. Rev. Pharmacol. Toxicol. 49, 327-347. doi: 10.1146/annurev.pharmtox.011008.145634

Bigalke, B., Schreitmuller, B., Sopova, K., Paul, A., Stransky, E., Gawaz, M., et al. (2011). Adipocytokines and CD34 progenitor cells in Alzheimer's disease. PloS One 6:e20286. doi: 10.1371/journal.pone.0020286

Bingham, E. M., Hopkins, D., Smith, D., Pernet, A., Hallett, W., Reed, L., et al. (2002). The role of insulin in human brain glucose metabolism: an 18 fluorodeoxyglucose positron emission tomography study. Diabetes 51, 3384-3390. doi: $10.2337 /$ diabetes.51.12.3384

Blum, K., Braverman, E. R., Holder, J. M., Lubar, J. F., Monastra, V. J., Miller, D., et al. (2000). Reward deficiency syndrome: a biogenetic model for the diagnosis and treatment of impulsive, addictive and compulsive behaviors. J. Psychoactive Drugs 32, 1-112. doi: 10.1080/02791072.2000.10736099

Blum, K., Thanos, P. K., and Gold, M. S. (2014). Dopamine and glucose, obesity and reward deficiency syndrome. Front. Psychol. 5:919. doi: 10.3389/fpsyg. 2014.00919

Bomfim, T. R., Forny-Germano, L., Sathler, L. B., Brito-Moreira, J., Houzel, J. C., Decker, H., et al. (2012). An anti-diabetes agent protects the mouse brain from defective insulin signaling caused by Alzheimer's disease- associated $\mathrm{A} \beta$ oligomers. J. Clin. Invest. 122, 1339-1353. doi: 10.1172/JCI57256

Boulton, A. J., Vinik, A. I., Arezzo, J. C., Bril, V., Feldman, E. L., Freeman, R., et al. (2005). Diabetic neuropathies: a statement by the American Diabetes Association. Diabetes Care 28, 956-962. doi: 10.2337/diacare. 28.4.956

Bousquet, M., St-Amour, I., Vandal, M., Julien, P., Cicchetti, F., and Calon, F. (2012). High-fat diet exacerbates MPTP-induced dopaminergic degeneration in mice. Neurobiol. Dis. 45, 529-538. doi: 10.1016/j.nbd.2011. 09.009
Braunwald, E. (1997). Shattuck lecture-cardiovascular medicine at the turn of the millennium: triumphs, concerns and opportunities. N. Engl. J. Med. 337, 1360-1369. doi: 10.1056/nejm199711063371906

Bromberg-Martin, E. S., Matsumoto, M., and Hikosaka, O. (2010). Dopamine in motivational control: rewarding, aversive and alerting. Neuron 68, 815-834. doi: 10.1016/j.neuron.2010.11.022

Brownlee, M. (2001). Biochemistry and molecular cell biology of diabetic complications. Nature 414, 813-820. doi: 10.1038/414813a

Brück, A., Aalto, S., Nurmi, E., Bergman, J., and Rinne, J. O. (2005). Cortical $6^{-18}$ fluoro-L-dopa uptake and frontal cognitive functions in early Parkinson's disease. Neurobiol. Aging 26, 891-898. doi: 10.1016/j.neurobiolaging.2004. 07.014

Brück, A., Portin, R., Lindell, A., Laihinen, A., Bergman, J., Haaparanta, M., et al. (2001). Positron emission tomography shows that impaired frontal lobe functioning in Parkinson's disease is related to dopaminergic hypofunction in the caudate nucleus. Neurosci. Lett. 311, 81-84. doi: 10.1016/s03043940(01)02124-3

Brunerova, L., Potockova, J., Horacek, J., Suchy, J., and Andel, M. (2013). Central dopaminergic activity influences metabolic parameters in healthy men. Neuroendocrinology 97, 132-138. doi: 10.1159/000338405

Buchman, A. S., Wilson, R. S., Bienias, J. L., Shah, R. C., Evans, D. A., and Bennett, D. A. (2005). Change in body mass index and risk of incident Alzheimer's disease. Neurology 65, 892-897. doi: 10.1212/01.wnl.0000176061. 33817.90

Burbulla, L. F., Schelling, C., Kato, H., Rapaport, D., Woitalla, D., Schiesling, C., et al. (2010). Dissecting the role of the mitochondrial chaperone mortalin in Parkinson's disease: functional impact of disease-related variants on mitochondrial homeostasis. Hum. Mol. Genet. 19, 4437-4452. doi: 10. $1093 / \mathrm{hmg} / \mathrm{ddq} 370$

Cai, D. (2009). NFkappaB-mediated metabolic inflammation in peripheral tissues versus central nervous system. Cell Cycle 8, 2542-2548. doi: 10.4161/cc.8.16. 9386

Calabresi, P., Picconi, B., Tozzi, A., Ghiglieri, V., and Di Filippo, M. (2014). Direct and indirect pathways of basal ganglia: a critical reappraisal. Nat. Neurosci. 17, 1022-1030. doi: 10.1038/nn.3743

Carvelli, L., Moron, J. A., Kahlig, K. M., Ferrer, J. V., Sen, N., Lechleiter, J. D., et al. (2002). PI 3-kinase regulation of dopamine uptake. J. Neurochem. 81, 859-869. doi: 10.1046/j.1471-4159.2002.00892.x

Chai, S. Y., Mendelsohn, F. A., and Paxinos, G. (1987). Angiotensin converting enzyme in rat brain visualized by quantitative in vitro autoradiography. Neuroscience 20, 615-627. doi: 10.1016/0306-4522(87)90114-x

Chase, T. N., Oh, J. D., and Blanchet, P. J. (1998). Neostriatal mechanisms in Parkinson's disease. Neurology 51, S30-S35. doi: 10.1212/wnl.51.2_suppl_2.s30

Chen, H. H., AbouEzzeddine, O. F., Anstrom, K. J., Givertz, M. M., Bart, B. A., Felker, G. M., et al. (2013). Targeting the kidney in acute heart failure: can old drugs provide new benefit? Renal optimization strategies evaluation in acute heart failure (ROSE AHF) trial. Circ. Heart Fail. 6, 1087-1094. doi: 10. 1161/CIRCHEARTFAILURE.113.000347

Chen, Y., and Dorn, G. W., 2nd (2013). PINK1-phosphorylated mitofusin 2 is a Parkin receptor for culling damaged mitochondria. Science 340, 471-475. doi: 10.1126/science.1231031

Chen, P. S., Yang, Y. K., Yeh, T. L., Lee, I. H., Yao, W. J., Chiu, N. T., et al. (2008). Correlation between body mass index and striatal dopamine transporter availability in healthy volunteers-a SPECT study. Neuroimage 40, 275-279. doi: 10.1016/j.neuroimage.2007.11.007

Cheng, G., Huang, C., Deng, H., and Wang, H. (2012). Diabetes as a risk factor for dementia and mild cognitive impairment: a meta-analysis of longitudinal studies. Intern. Med. J. 42, 484-491. doi: 10.1111/j.1445-5994.2012.02758.x

Cheng, B., Maffi, S. K., Martinez, A. A., Acosta, Y. P., Morales, L. D., and Roberts, J. L. (2011). Insulin-like growth factor-I mediates neuroprotection in proteasome inhibition-induced cytotoxicity in SH-SY5Y cells. Mol. Cell. Neurosci. 47, 181-190. doi: 10.1016/j.mcn.2011.04.002

Cholerton, B., Baker, L. D., and Craft, S. (2011). Insulin resistance and pathological brain ageing. Diabet. Med. 28, 1463-1475. doi: 10.1111/j.1464-5491.2011. 03464.x

Cilia, R., Cereda, E., Klersy, C., Canesi, M., Zecchinelli, A. L., Mariani, C. B., et al. (2015). Parkinson's disease beyond 20 years. J. Neurol. Neurosurg. Psychiatry 86, 849-855. doi: 10.1136/jnnp-2014-308786 
Cincotta, A. H., Tozzo, E., and Scislowski, P. W. (1997). Bromocriptine/SKF38393 treatment ameliorates obesity and associated metabolic dysfunctions in obese (ob/ob) mice. Life Sci. 61, 951-956. doi: 10.1016/s0024-3205(97) 00599-7

Conti, G., Blandini, F., Tassorelli, C., Giubilei, F., Fornai, F., Zocchi, A., et al. (2001). Intrastriatal injection of D1 or D2 dopamine agonists affects glucose utilization in both the direct and indirect pathways of the rat basal ganglia. Neurosci. Lett. 309, 161-164. doi: 10.1016/s0304-3940(01)02068-7

Cools, R. (2011). Dopaminergic control of the striatum for high-level cognition. Curr. Opin. Neurobiol. 21, 402-407. doi: 10.1016/j.conb.2011.04.002

Corti, O., Lesage, S., and Brice, A. (2011). What genetics tells us about the causes and mechanisms of Parkinson's disease. Physiol. Rev. 91, 1161-1218. doi: 10. $1152 /$ physrev.00022.2010

Cui, H., Kong, Y., and Zhang, H. (2012). Oxidative stress, mitochondrial dysfunction and aging. J. Signal Transduct. 2012:646354. doi: 10. $1155 / 2012 / 646354$

Curtis, C., and Davis, C. (2014). A qualitative study of binge eating and obesity from an addiction perspective. Eat. Disord. 22, 19-32. doi: 10.1080/10640266. 2014.857515

Dauer, W., and Przedborski, S. (2003). Parkinson's disease: mechanisms and models. Neuron 39, 889-909. doi: 10.1016/S0896-6273(03)00568-3

Davis, J. F., Choi, D. L., Schurdak, J. D., Fitzgerald, M. F., Clegg, D. J., Lipton, J. W., et al. (2011). Leptin regulates energy balance and motivation through action at distinct neural circuits. Biol. Psychiatry 69, 668-674. doi: 10.1016/j.biopsych. 2010.08.028

Dehay, B., Bourdenx, M., Gorry, P., Przedborski, S., Vila, M., Hunot, S., et al. (2015). Targeting alpha-synuclein for treatment of Parkinson's disease: mechanistic and therapeutic considerations. Lancet Neurol. 14, 855-866. doi: 10.1016/S1474-4422(15)00006-x

Dillin, A., Hsu, A. L., Arantes-Oliveira, N., Lehrer-Graiwer, J., Hsin, H., Fraser, A. G., et al. (2002). Rates of behavior and aging specified by mitochondrial function during development. Science 298, 2398-2401. doi: 10. 1126/science. 1077780

Dobbs, R. J., Charlett, A., Purkiss, A. G., Dobbs, S. M., Weller, C., and Peterson, D. W. (1999). Association of circulating TNF-alpha and IL-6 with ageing and parkinsonism. Acta Neurol. Scand. 100, 34-41. doi: 10.1111/j.16000404.1999.tb00721.x

Doorn, K. J., Goudriaan, A., Blits-Huizinga, C., Bol, J. G., Rozemuller, A. J., Hoogland, P. V., et al. (2014a). Increased amoeboid microglial density in the olfactory bulb of Parkinson's and Alzheimer's patients. Brain Pathol. 24, 152-165. doi: 10.1111/bpa.12088

Doorn, K. J., Moors, T., Drukarch, B., van de Berg, W., Lucassen, P. J., and van Dam, A. M. (2014b). Microglial phenotypes and toll-like receptor 2 in the substantia nigra and hippocampus of incidental Lewy body disease cases and Parkinson's disease patients. Acta Neuropathol. Commun. 2:90. doi: 10. 1186/s40478-014-0090-1

Dunn, J. D., and Castro, A. J. (1980). Altered but persisting circadian fluctuations in plasma corticosterone levels following medial forebrain bundle ablation. Neurosci. Lett. 19, 93-96. doi: 10.1016/0304-3940(80)90262-1

Emamian, E. S., Hall, D., Birnbaum, M. J., Karayiorgou, M., and Gogos, J. A. (2004). Convergent evidence for impaired AKT1-GSK3 $\beta$ signaling in schizophrenia. Nat. Genet. 36, 131-137. doi: 10.1038/ng1296

Farr, S. A., Banks, W. A., and Morley, J. E. (2006). Effects of leptin on memory processing. Peptides 27, 1420-1425. doi: 10.1016/j.peptides.2005.10.006

Fatima, S., Haque, R., Jadiya, P., Shamsuzzama, , Kumar, L., and Nazir, A. (2014). Ida-1, the Caenorhabditis elegans orthologue of mammalian diabetes autoantigen IA-2, potentially acts as a common modulator between Parkinson's disease and Diabetes: role of Daf-2/Daf-16 insulin like signalling pathway. PLoS One 9:e113986. doi: 10.1371/journal.pone.0113986

Figlewicz, D. P., and Benoit, S. C. (2009). Insulin, leptin and food reward: update 2008. Am. J. Physiol. Regul. Integr. Comp. Physiol. 296, R9-R19. doi: 10. 1152/ajpregu.90725.2008

Figlewicz, D. P., and Sipols, A. J. (2010). Energy regulatory signals and food reward. Pharmacol. Biochem. Behav. 97, 15-24. doi: 10.1016/j.pbb.2010. 03.002

Figlewicz, D. P., Evans, S. B., Murphy, J., Hoen, M., and Baskin, D. G. (2003). Expression of receptors for insulin and leptin in the ventral tegmental area/substantia nigra (VTA/SN) of the rat. Brain Res. 964, 107-115. doi: 10. 1016/s0006-8993(02)04087-8
Figlewicz, D. P., Szot, P., Chavez, M., Woods, S. C., and Veith, R. C. (1994). Intraventricular insulin increases dopamine transporter mRNA in rat VTA/substantia nigra. Brain Res. 644, 331-334. doi: 10.1016/00068993(94)91698-5

Frank-Cannon, T. C., Alto, L. T., McAlpine, F. E., and Tansey, M. G. (2009). Does neuroinflammation fan the flame in neurodegenerative diseases? Mol. Neurodegener. 4:47. doi: 10.1186/1750-1326-4-47

Freeman, A. S., Weddige, F. K., and Lipinski, J. L., Jr. (2001). Effect of glucose on antipsychotic drug-induced changes in dopamine neuronal activity. Eur. J. Pharmacol. 431, 43-46. doi: 10.1016/s0014-2999(01)01408-x

Garcia, B. G., Wei, Y., Moron, J. A., Lin, R. Z., Javitch, J. A., and Galli, A. (2005). Akt is essential for insulin modulation of amphetamine-induced human dopamine transporter cell-surface redistribution. Mol. Pharmacol. 68, 102-109. doi: 10.1124/mol.104.009092

Giaccari, A., Sorice, G., and Muscogiuri, G. (2009). Glucose toxicity: the leading actor in the pathogenesis and clinical history of type 2 diabetes - mechanisms and potentials for treatment. Nutr. Metab. Cardiovasc. Dis. 19, 365-377. doi: 10. 1016/j.numecd.2009.03.018

Gildea, J. J. (2009). Dopamine and angiotensin as renal counterregulatory systems controlling sodium balance. Curr. Opin. Nephrol. Hypertens. 18, 28-32. doi: 10. 1097/MNH.0b013e32831a9e0b

Goldstein, D. S. (2006). Cardiovascular aspects of Parkinson's disease. J. Neural Transm. Suppl. 70, 339-342. doi: 10.1007/978-3-211-45295-0_51

Goldstein, D. S., Holmes, C., Bentho, O., Sato, T., Moak, J., Sharabi, Y., et al. (2008). Biomarkers to detect central dopamine deficiency and distinguish Parkinson disease from multiple system atrophy. Parkinsonism Relat. Disord. 14, 600-607. doi: 10.1016/j.parkreldis.2008.01.010

Goldstein, D. S., Holmes, C., Kopin, I. J., and Sharabi, Y. (2011). Intra-neuronal vesicular uptake of catecholamines is decreased in patients with Lewy body diseases. J. Clin. Invest. 121, 3320-3330. doi: 10.1172/JCI45803

Goldstein, D. S., Holmes, C., Sewell, L., Park, M. Y., and Sharabi, Y. (2012). Sympathetic noradrenergic before striatal dopaminergic denervation: relevance to Braak staging of synucleinopathy. Clin. Auton. Res. 22, 57-61. doi: 10. 1007/s10286-011-0136-4

Goldstein, D. S., Sharabi, Y., Karp, B. I., Bentho, O., Saleem, A., Pacak, K., et al. (2007). Cardiac sympathetic denervation preceding motor signs in Parkinson disease. Clin. Auton. Res. 17, 118-121. doi: 10.1007/s10286-007-0396-1

Gudala, K., Bansal, D., Schifano, F., and Bhansali, A. (2013). Diabetes mellitus and risk of dementia: a meta-analysis of prospective observational studies. J. Diabetes Investig. 4, 640-650. doi: 10.1111/jdi.12087

Hage Hassan, R., Pacheco de Sousa, A. C., Mahfouz, R., Hainault, I., BlachnioZabielska, A., Bourron, O., et al. (2015). Sustained action of ceramide on the insulin signaling pathway in muscle cells: implication of the double-stranded RNA activated protein kinase. J. Biol. Chem. 291, 3019-3029. doi: 10.1074/jbc. m115.686949

Hamdi, A., Porter, J., and Prasad, C. (1992). Decreased striatal D2 dopamine receptors in obese Zucker rats: changes during aging. Brain Res. 589, 338-340. doi: 10.1016/0006-8993(92)91296-q

Hanada, M., Feng, J., and Hemmings, B. A. (2004). Structure, regulation and function of PKB/AKT-a major therapeutic target. Biochim. Biophys. Acta 1697, 3-16. doi: 10.1016/j.bbapap.2003.11.009

Hartmann, A., and Hirsch, E. C. (2001). Parkinson's disease. The apoptosis hypothesis revisited. Adv. Neurol. 86, 143-153. doi: 10.1075/z.106.07

Hess, M. E., Hess, S., Meyer, K. D., Verhagen, L. A., Koch, L., Brönneke, H. S., et al. (2013). The fat mass and obesity associated gene (Fto) regulates activity of the dopaminergic midbrain circuitry. Nat. Neurosci. 16, 1042-1048. doi: 10. 1038/nn.3449

Hinnouho, G. M., Czernichow, S., Dugravot, A., Nabi, H., Brunner, E. J., Kivimaki, M., et al. (2015). Metabolically healthy obesity and the risk of cardiovascular disease and type 2 diabetes: the Whitehall II cohort study. Eur. Heart J. 36, 551-559. doi: 10.1093/eurheartj/ehu123

Hisanaga, K., Asagi, M., Itoyama, Y., and Iwasaki, Y. (2001). Increase in peripheral CD4 bright+ CD8 dull + T cells in Parkinson's disease. Arch. Neurol. 58, 1580-1583. doi: 10.1001/archneur.58.10.1580

Hu, G., Jousilahti, P., Bidel, S., Antikainen, R., and Tuomilehto, J. (2007). Type 2 diabetes and the risk of Parkinson's disease. Diabetes Care 30, 842-847. doi: 10. 2337/dc06-2011

Ikeda, M., Iwata, N., Suzuki, T., Kitajima, T., Yamanouchi, Y., Kinoshiya, Y., et al. (2006). Positive association of AKT1 haplotype to Japanese 
methamphetamine use disorder. Int. J. Neuropsychopharmacol. 9, 77-81. doi: $10.1017 /$ s1461145705005481

Jenkins, T. A., Mendelsohn, F. A., and Chai, S. Y. (1997). Angiotensin-converting enzyme modulates dopamine turnover in the striatum. J. Neurochem. 68, 1304-1311. doi: 10.1046/j.1471-4159.1997.68031304.x

Jenkins, T. A., Wong, J. Y., Howells, D. W., Mendelsohn, F. A., and Chai, S. Y. (1999). Effect of chronic angiotensin-converting enzyme inhibition on striatal dopamine content in the MPTP-treated mouse. J. Neurochem. 73, 214-219. doi: 10.1046/j.1471-4159.1999.0730214.x

Jeon, B. S., Jackson-Lewis, V., and Burke, R. E. (1995). 6-Hydroxydopamine lesion of the rat substantia nigra: time course and morphology of cell death. Neurodegeneration 4, 131-137. doi: 10.1006/neur.1995.0016

Jokinen, P., Brück, A., Aalto, S., Forsback, S., Parkkola, R., and Rinne, J. O. (2009). Impaired cognitive performance in Parkinson's disease is related to caudate dopaminergic hypofunction and hippocampal atrophy. Parkinsonism Relat. Disord. 15, 88-93. doi: 10.1016/j.parkreldis.2008.03.005

Kalia, L. V., and Lang, A. E. (2015). Parkinson's disease. Lancet 386, 896-912. doi: 10.1016/S0140-6736(14)61393-3

Kallio, M., Haapaniemi, T., Turkka, J., Suominen, K., Tolonen, U., Sotaniemi, K., et al. (2000). Heart rate variability in patients with untreated Parkinson's disease. Eur. J. Neurol. 7, 667-672. doi: 10.1046/j.1468-1331.2000. 00127.x

Kalyani, R. R., Corriere, M., and Ferrucci, L. (2014). Age-related and disease-related muscle loss: the effect of diabetes, obesity and other diseases. Lancet Diabetes Endocrinol. 2, 819-829. doi: 10.1016/s2213-8587(14) 70034-8

Kann, O., and Kovács, R. (2007). Mitochondria and neuronal activity. Am. J. Physiol. Cell Physiol. 292, C641-C657. doi: 10.1152/ajpcell.00222.2006

Karachi, C., Grabli, D., Bernard, F. A., Tandé, D., Wattiez, N., Belaid, H., et al. (2010). Cholinergic mesencephalic neurons are involved in gait and postural disorders in Parkinson disease. J. Clin. Invest. 120, 2745-2754. doi: 10. $1172 /$ JCI 42642

Kastin, A. J., and Akerstrom, V. (2001). Glucose and insulin increase the transport of leptin through the blood-brain barrier in normal mice but not in streptozotocin-diabetic mice. Neuroendocrinology 73, 237-242. doi: 10. $1159 / 000054640$

Khan, F., Spicarová, Z., Zelenin, S., Holtbäck, U., Scott, L., and Aperia, A. (2008). Negative reciprocity between angiotensin II type 1 and dopamine D1 receptors in rat renal proximal tubule cells. Am. J. Physiol. Renal Physiol. 295, F1110-F1116. doi: 10.1152/ajprenal.90336.2008

Khang, R., Park, C., and Shin, J. H. (2015). Dysregulation of parkin in the substantia nigra of db/db and high-fat diet mice. Neuroscience 294, 182-192. doi: 10.1016/j.neuroscience.2015.03.017

Khanh, D. V., Choi, Y. H., Moh, S. H., Kinyua, A. W., and Kim, K. W. (2014). Leptin and insulin signaling in dopaminergic neurons: relationship between energy balance and reward system. Front. Psychol. 5:846. doi: 10.3389/fpsyg. 2014.00846

Kim, S. J., and Han, Y. (2005). Insulin inhibits AMPA-induced neuronal damage via stimulation of protein kinase B (Akt). J. Neural. Transm. (Vienna) 112, 179-191. doi: 10.1007/s00702-004-0163-6

Kleinridders, A., Cai, W., Cappellucci, L., Ghazarian, A., Collins, W. R., Vienberg, S. G., et al. (2015). Insulin resistance in brain alters dopamine turnover and causes behavioral disorders. Proc. Natl. Acad. Sci. U S A 112, 3463-3468. doi: 10.1073/pnas.1500877112

Kondo, T., Hafezi-Moghadam, A., Thomas, K., Wagner, D. D., and Kahn, C. R. (2004). Mice lacking insulin or insulin-like growth factor 1 receptors in vascular endothelial cells maintain normal blood-brain barrier. Biochem. Biophys. Res. Commun. 317, 315-320. doi: 10.1016/j.bbrc.2004.03.043

Könner, A. C., Hess, S., Tovar, S., Mesaros, A., Sánchez-Lasheras, C., Evers, N., et al. (2011). Role for insulin signaling in catecholaminergic neurons in control of energy homeostasis. Cell Metab. 13, 720-728. doi: 10.1016/j.cmet.2011. 03.021

Koshimura, K., Tanaka, J., Murakami, Y., and Kato, Y. (2003). Effect of high concentration of glucose on dopamine release from pheochromocytoma-12 cells. Metabolism 52, 922-926. doi: 10.1016/s0026-0495(03)00059-3

Kravitz, A. V., Freeze, B. S., Parker, P. R., Kay, K., Thwin, M. T., Deisseroth, K., et al. (2010). Regulation of parkinsonian motor behaviours by optogenetic control of basal ganglia circuitry. Nature 466, 622-626. doi: 10 . 1038/nature09159
Landau, S. M., Lal, R., O’Neil, J. P., Baker, S., and Jagust, W. J. (2009). Striatal dopamine and working memory. Cereb. Cortex 19, 445-454. doi: 10. 1093/cercor/bhn095

Langbaum, J. B., Chen, K., Launer, L. J., Fleisher, A. S., Lee, W., Liu, X., et al. (2012). Blood pressure is associated with higher brain amyloid burden and lower glucose metabolism in healthy late middle-age persons. Neurobiol. Aging 33, 827.e11-829.e19. doi: 10.1016/j.neurobiolaging.2011.06.020

Lara, V. P., Caramelli, P., Teixeira, A. L., Barbosa, M. T., Carmona, K. C., Carvalho, M. G., et al. (2013). High cortisol levels are associated with cognitive impairment no-dementia (CIND) and dementia. Clin. Chim. Acta 423, 18-22. doi: 10.1016/j.cca.2013.04.013

Lawson, L. J., Perry, V. H., Dri, P., and Gordon, S. (1990). Heterogeneity in the distribution and morphology of microglia in the normal adult mouse brain. Neuroscience 39, 151-170. doi: 10.1016/0306-4522(90)90229-w

Lee, S. S., Lee, R. Y., Fraser, A. G., Kamath, R. S., Ahringer, J., and Ruvkun, G. (2003). A systematic RNAi screen identifies a critical role for mitochondria in C. elegans longevity. Nat. Genet. 33, 40-48. doi: 10.1038/ng1056

Levin, B. E., Llabre, M. M., Dong, C., Elkind, M. S., Stern, Y., Rundek, T., et al. (2014). Modeling metabolic syndrome and its association with cognition: the Northern Manhattan study. J. Int. Neuropsychol. Soc. 20, 951-960. doi: 10. $1017 /$ s 1355617714000861

Li, H., Armando, I., Yu, P., Escano, C., Mueller, S. C., Asico, L., et al. (2008). Dopamine 5 receptor mediates Ang II type 1 receptor degradation via a ubiquitin-proteasome pathway in mice and human cells. J. Clin. Invest. 118, 2180-2189. doi: 10.1172/JCI33637

Li, D. W., Li, G. R., Zhang, B. L., Feng, J. J., and Zhao, H. (2016). Damage to dopaminergic neurons is mediated by proliferating cell nuclear antigen through the $\mathrm{p} 53$ pathway under conditions of oxidative stress in a cell model of Parkinson's disease. Int. J. Mol. Med. 37, 429-435. doi: 10.3892/ijmm.2015. 2430

Li, B. M., and Mei, Z. T. (1994). Delayed-response deficit induced by local injection of the alpha 2-adrenergic antagonist yohimbine into the dorsolateral prefrontal cortex in young adult monkeys. Behav. Neural Biol. 62, 134-139. doi: 10. 1016/s0163-1047(05)80034-2

Liang, K. V., Williams, A. W., Greene, E. L., and Redfield, M. M. (2008). Acute decompensated heart failure and the cardiorenal syndrome. Crit Care Med. 36, S75-S88. doi: 10.1097/01.CCM.0000296270.41256.5C

Lotharius, J., Dugan, L. L., and O'Malley, K. L. (1999). Distinct mechanisms underlie neurotoxin-mediated cell death in cultured dopaminergic neurons. J. Neurosci. 19, 1284-1293.

Lu, M., and Hu, G. (2012). Targeting metabolic inflammation in Parkinson's disease: implications for prospective therapeutic strategies. Clin. Exp. Pharmacol. Physiol. 39, 577-585. doi: 10.1111/j.1440-1681.2011.05650.x

Luchsinger, J. A. (2010). Type 2 diabetes, related conditions, in relation and dementia: an opportunity for prevention? J. Alzheimers Dis. 20, 723-736. doi: 10.3233/JAD-2010-091687

Luo, S., Liang, Y., and Cincotta, A. H. (1999). Intracerebroventricular administration of bromocriptine ameliorates the insulin-resistant/glucoseintolerant state in hamsters. Neuroendocrinology 69, 160-166. doi: 10. $1159 / 000054415$

Lyzogub, V. H., Sobol, V. O., Moshkovs'ka Iu, O., and Bondarchuk, O. M. (2014). Influence of dopamine receptors agonists on clinical and hemodynamic and neurohumoral indicators in hypertensive patients with concomitant obesity. Lik. Sprava 67-72.

Machado, A., Herrera, A. J., Venero, J. L., Santiago, M., De Pablos, R. M., Villaran, R. F., et al. (2011). Peripheral inflammation increases the damage in animal models of nigrostriatal dopaminergic neurodegeneration: possible implication in Parkinson's disease incidence. Parkinsons. Dis. 2011:393769. doi: $10.4061 / 2011 / 393769$

Martorell-Riera, A., Segarra-Mondejar, M., Muñoz, J. P., Ginet, V., Olloquequi, J., Pérez-Clausell, J., et al. (2014). Mfn2 downregulation in excitotoxicity causes mitochondrial dysfunction and delayed neuronal death. EMBO J. 33, 2388-2407. doi: 10.15252/embj.201488327

Masoud, S. T., Vecchio, L. M., Bergeron, Y., Hossain, M. M., Nguyen, L. T., Bermejo, M. K., et al. (2015). Increased expression of the dopamine transporter leads to loss of dopamine neurons, oxidative stress and 1-DOPA reversible motor deficits. Neurobiol. Dis. 74, 66-75. doi: 10.1016/j.nbd.2014.10.016

McGeer, P. L., and McGeer, E. G. (2008). Glial reactions in Parkinson's disease. Mov. Disord. 23, 474-483. doi: 10.1002/mds.21751 
McNay, E. C., Ong, C. T., McCrimmon, R. J., Cresswell, J., Bogan, J. S., and Sherwin, R. S. (2010). Hippocampal memory processes are modulated by insulin and high-fat-induced insulin resistance. Neurobiol. Learn. Mem. 93, 546-553. doi: 10.1016/j.nlm.2010.02.002

Michaelides, M., Thanos, P. K., Kim, R., Cho, J., Ananth, M., Wang, G. J., et al. (2012). PET imaging predicts future body weight and cocaine preference. Neuroimage 59, 1508-1513. doi: 10.1016/j.neuroimage.2011.08.028

Michel, P. P., Toulorge, D., Guerreiro, S., and Hirsch, E. C. (2013). Specific needs of dopamine neurons for stimulation in order to survive: implication for Parkinson disease. FASEB J. 27, 3414-3423. doi: 10.1096/fj.12-220418

Moroo, I., Yamada, T., Makino, H., Tooyama, I., McGeer, P. L., McGeer, E. G., et al. (1994). Loss of insulin receptor immunoreactivity from the substantia nigra pars compacta neurons in Parkinson's disease. Acta Neuropathol. 87, 343-348. doi: 10.1007/bf00313602

Morris, J. K., Bomhoff, G. L., Stanford, J. A., and Geiger, P. C. (2010). Neurodegeneration in an animal model of Parkinson's disease is exacerbated by a high-fat diet. Am. J. Physiol. Regul. Integr. Comp. Physiol. 299, R1082-R1090. doi: 10.1152/ajpregu.00449.2010

Mosharov, E. V., Larsen, K. E., Kanter, E., Phillips, K. A., Wilson, K., Schmitz, Y., et al. (2009). Interplay between cytosolic dopamine, calcium and $\alpha$-synuclein causes selective death of substantia nigra neurons. Neuron 62, 218-229. doi: 10. 1016/j.neuron.2009.01.033

Nair, V. D. (2006). Activation of p53 signaling initiates apoptotic death in a cellular model of Parkinson's disease. Apoptosis 11, 955-966. doi: 10.1007/s10495-0066316-3

Narayanan, N. S., Rodnitzky, R. L., and Uc, E. Y. (2013). Prefrontal dopamine signaling and cognitive symptoms of Parkinson's disease. Rev. Neurosci. 24, 267-278. doi: 10.1515/revneuro-2013-0004

Ninomiya, T. (2014). Diabetes mellitus and dementia. Curr. Diab. Rep. 14:487. doi: 10.1007/s11892-014-0487-z

Orimo, S., Oka, T., Miura, H., Tsuchiya, K., Mori, F., Wakabayashi, K., et al. (2002). Sympathetic cardiac denervation in Parkinson's disease and pure autonomic failure but not in multiple system atrophy. J. Neurol. Neurosurg. Psychiatry 73, 776-777. doi: 10.1136/jnnp.73.6.776

Ouchi, Y., Yoshikawa, E., Sekine, Y., Futatsubashi, M., Kanno, T., Ogusu, T., et al. (2005). Microglial activation and dopamine terminal loss in early Parkinson's disease. Ann. Neurol. 57, 168-175. doi: 10.1002/ana.20338

Owens, W. A., Sevak, R. J., Galici, R., Chang, X., Javors, M. A., Galli, A., et al. (2005). Deficits in dopamine clearance and locomotion in hypoinsulinemic rats unmask novel modulation of dopamine transporters by amphetamine. J. Neurochem. 94, 1402-1410. doi: 10.1111/j.1471-4159.2005.03289.x

Palmiter, R. D. (2007). Is dopamine a physiologically relevant mediator of feeding behavior? Trends Neurosci. 30, 375-381. doi: 10.1016/j.tins.2007.06.004

Palmiter, R. D. (2008). Dopamine signaling in the dorsal striatum is essential for motivated behaviors: lessons from dopamine-deficient mice. Ann. N Y Acad. Sci. 1129, 35-46. doi: 10.1196/annals.1417.003

Pang, Y., Lin, S., Wright, C., Shen, J., Carter, K., Bhatt, A., et al. (2016). Intranasal insulin protects against substantia nigra dopaminergic neuronal loss and alleviates motor deficits induced by 6-OHDA in rats. Neuroscience 318, 157-165. doi: 10.1016/j.neuroscience.2016.01.020

Patterson, T. A., Brot, M. D., Zavosh, A., Schenk, J. O., Szot, P., and Figlewicz, D. P. (1998). Food deprivation decreases mRNA and activity of the rat dopamine transporter. Neuroendocrinology 68, 11-20. doi: 10.1159/000054345

Pearce, R. K., Owen, A., Daniel, S., Jenner, P., and Marsden, C. D. (1997). Alterations in the distribution of glutathione in the substantia nigra in Parkinson's disease. J. Neural. Transm. (Vienna) 104, 661-677. doi: 10. 1007/bf01291884

Perry, V. H. (2012). Innate inflammation in Parkinson's disease. Cold Spring Harb. Perspect. Med. 2:a009373. doi: 10.1101/cshperspect.a009373

Pisanu, A., Lecca, D., Mulas, G., Wardas, J., Simbula, G., Spiga, S., et al. (2014). Dynamic changes in pro- and anti-inflammatory cytokines in microglia after PPAR-gamma agonist neuroprotective treatment in the MPTPp mouse model of progressive Parkinson's disease. Neurobiol. Dis. 71, 280-291. doi: 10.1016/j. nbd.2014.08.011

Qiu, C., Winblad, B., and Fratiglioni, L. (2005). The age-dependent relation of blood pressure to cognitive function and dementia. Lancet Neurol. 4, 487-499. doi: 10.1016/s1474-4422(05)70141-1

Reagan, L. P., Gorovits, N., Hoskin, E. K., Alves, S. E., Katz, E. B., Grillo, C. A., et al. (2001). Localization and regulation of GLUTx1 glucose transporter in the hippocampus of streptozotocin diabetic rats. Proc. Natl. Acad. Sci. U S A 98, 2820-2825. doi: 10.1073/pnas.051629798

Reale, M., Iarlori, C., Thomas, A., Gambi, D., Perfetti, B., Di Nicola, M., et al. (2009). Peripheral cytokines profile in Parkinson's disease. Brain Behav. Immun. 23, 55-63. doi: 10.1016/j.bbi.2008.07.003

Reardon, K. A., Mendelsohn, F. A., Chai, S. Y., and Horne, M. K. (2000). The angiotensin converting enzyme (ACE) inhibitor, perindopril, modifies the clinical features of Parkinson's disease. Aust. N. Z. J. Med. 30, 48-53. doi: 10. 1111/j.1445-5994.2000.tb01054.x

Renaud, J., Bournival, J., Zottig, X., and Martinoli, M. G. (2014). Resveratrol protects DAergic PC12 cells from high glucose-induced oxidative stress and apoptosis: effect on p53 and GRP75 localization. Neurotox. Res. 25, 110-123. doi: 10.1007/s12640-013-9439-7

Ribeiro, M., Rosenstock, T. R., Oliveira, A. M., Oliveira, C. R., and Rego, A. C. (2014). Insulin and IGF-1 improve mitochondrial function in a PI-3K/Aktdependent manner and reduce mitochondrial generation of reactive oxygen species in Huntington's disease knock-in striatal cells. Free Radic. Biol. Med. 74, 129-144. doi: 10.1016/j.freeradbiomed.2014.06.023

Riera, C. E., and Dillin, A. (2015). Tipping the metabolic scales towards increased longevity in mammals. Nat. Cell Biol. 17, 196-203. doi: 10.1038/ncb3107

Rodrigue, K. M., Rieck, J. R., Kennedy, K. M., Devous, M. D. Jr., Diaz-Arrastia, R., and Park, D. C. (2013). Risk factors for beta-amyloid deposition in healthy aging: vascular and genetic effects. JAMA Neurol. 70, 600-606. doi: 10. 1001/jamaneurol.2013.1342

Rodriguez, M., Morales, I., Rodriguez-Sabate, C., Sanchez, A., Castro, R., Brito, J. M., et al. (2014). The degeneration and replacement of dopamine cells in Parkinson's disease: the role of aging. Front. Neuroanat. 8:80. doi: 10. 3389/fnana.2014.00080

Rodríguez, M., Sabaté, M., and Troncoso, E. (1996). Time and frequency domain analysis for the assessment of heart autonomic control in Parkinson's disease. J. Neural Transm. (Vienna) 103, 447-454. doi: 10.1007/bf01276420

Rodriguez-Oroz, M. C., Jahanshahi, M., Krack, P., Litvan, I., Macias, R., Bezard, E., et al. (2009). Initial clinical manifestations of Parkinson's disease: features and pathophysiological mechanisms. Lancet Neurol. 8, 1128-1139. doi: 10. 1016/s1474-4422(09)70293-5

Roitman, M. F., Stuber, G. D., Phillips, P. E., Wightman, R. M., and Carelli, R. M. (2004). Dopamine operates as a subsecond modulator of food seeking. J. Neurosci. 24, 1265-1271. doi: 10.1523/jneurosci.3823-03.2004

Ryan, B. J., Hoek, S., Fon, E. A., and Wade-Martins, R. (2015). Mitochondrial dysfunction and mitophagy in Parkinson's: from familial to sporadic disease. Trends Biochem. Sci. 40, 200-210. doi: 10.1016/j.tibs.2015.02.003

Sadi, G., Pektaş, M. B., Koca, H. B., Tosun, M., and Koca, T. (2015). Resveratrol improves hepatic insulin signaling and reduces the inflammatory response in streptozotocin-induced diabetes. Gene 570, 213-220. doi: 10.1016/j.gene.2015. 06.019

Salamone, J. D., Cousins, M. S., and Snyder, B. J. (1997). Behavioral functions of nucleus accumbens dopamine: empirical and conceptual problems with the anhedonia hypothesis. Neurosci. Biobehav. Rev. 21, 341-359. doi: 10. 1016/s0149-7634(96)00017-6

Sandyk, R. (1993). The relationship between diabetes mellitus and Parkinson's disease. Int. J. Neurosci. 69, 125-130. doi: 10.3109/00207459309003322

Sawaguchi, T., and Goldman-Rakic, P. S. (1994). The role of D1-dopamine receptor in working memory: local injections of dopamine antagonists into the prefrontal cortex of rhesus monkeys performing an oculomotor delayedresponse task. J. Neurophysiol. 71, 515-528.

Sawamoto, N., Piccini, P., Hotton, G., Pavese, N., Thielemans, K., and Brooks, D. J. (2008). Cognitive deficits and striato-frontal dopamine release in Parkinson's disease. Brain 131, 1294-1302. doi: 10.1093/brain/awn054

Segura-Aguilar, J., Paris, I., Muñoz, P., Ferrari, E., Zecca, L., and Zucca, F. A. (2014). Protective and toxic roles of dopamine in Parkinson's disease. J. Neurochem. 129, 898-915. doi: 10.1111/jnc.12686

Sepúlveda, J., and Murray, C. (2014). The state of global health in 2014. Science 345, 1275-1278. doi: 10.1126/science.1257099

Short, K. R., Bigelow, M. L., Kahl, J., Singh, R., Coenen-Schimke, J., Raghavakaimal, S., et al. (2005). Decline in skeletal muscle mitochondrial function with aging in humans. Proc. Natl. Acad. Sci. U S A 102, 5618-5623. doi: 10.1073/pnas.0501559102

Siuta, M. A., Robertson, S. D., Kocalis, H., Saunders, C., Gresch, P. J., Khatri, V., et al. (2010). Dysregulation of the norepinephrine transporter sustains cortical 
hypodopaminergia and schizophrenia-like behaviors in neuronal rictor null mice. PLoS Biol. 8:e1000393. doi: 10.1371/journal.pbio.1000393

Speed, N., Saunders, C., Davis, A. R., Owens, W. A., Matthies, H. J., Saadat, S., et al. (2011). Impaired striatal Akt signaling disrupts dopamine homeostasis and increases feeding. PLoS One 6:e25169. doi: 10.1371/journal.pone.0025169

Stice, E., Spoor, S., Bohon, C., and Small, D. M. (2008). Relation between obesity and blunted striatal response to food is moderated by TaqIA A1 allele. Science 322, 449-452. doi: 10.1126/science.1161550

Stice, E., Yokum, S., Blum, K., and Bohon, C. (2010). Weight gain is associated with reduced striatal response to palatable food. J. Neurosci. 30, 13105-13109. doi: 10.1523/JNEUROSCI.2105-10.2010

Stott, S. R., and Barker, R. A. (2014). Time course of dopamine neuron loss and glial response in the 6-OHDA striatal mouse model of Parkinson's disease. Eur. J. Neurosci. 39, 1042-1056. doi: 10.1111/ejn.12459

Sun, Y., Chang, Y. H., Chen, H. F., Su, Y. H., Su, H. F., and Li, C. Y. (2012). Risk of Parkinson disease onset in patients with diabetes: a 9-year population-based cohort study with age and sex stratifications. Diabetes Care 35, 1047-1049. doi: $10.2337 / \mathrm{dc} 11-1511$

Sun, X., Yao, H., Douglas, R. M., Gu, X. Q., Wang, J., and Haddad, G. G. (2010). Insulin/PI3K signaling protects dentate neurons from oxygen-glucose deprivation in organotypic slice cultures. J. Neurochem. 112, 377-388. doi: 10. 1111/j.1471-4159.2009.06450.x

Szczypka, M. S., Rainey, M. A., and Palmiter, R. D. (2000). Dopamine is required for hyperphagia in Lep(ob/ob) mice. Nat. Genet. 25, 102-104. doi: 10. $1038 / 75484$

Talbot, K., Wang, H. Y., Kazi, H., Han, L. Y., Bakshi, K. P., Stucky, A., et al. (2012). Demonstrated brain insulin resistance in Alzheimer's disease patients is associated with IGF-1 resistance, IRS-1 dysregulation and cognitive decline. J. Clin. Invest. 122, 1316-1338. doi: 10.1172/JCI59903

Tang, Y., Purkayastha, S., and Cai, D. (2015). Hypothalamic microinflammation: a common basis of metabolic syndrome and aging. Trends Neurosci. 38, 36-44. doi: 10.1016/j.tins.2014.10.002

Tatton, N. A. (2000). Increased caspase 3 and Bax immunoreactivity accompany nuclear GAPDH translocation and neuronal apoptosis in Parkinson's disease. Exp. Neurol. 166, 29-43. doi: 10.1006/exnr.2000.7489

Tezapsidis, N., Smith, M. A., and Ashford, J. W. (2009). Central obesity and increased risk of dementia more than three decades later. Neurology 72 , 1030-1031; author reply 1031. doi: 10.1212/01.wnl.0000343499.72241.ea

Theodoropoulou, A., Metallinos, I. C., Psyrogiannis, A., Vagenakis, G. A., and Kyriazopoulou, V. (2012). Ghrelin and leptin secretion in patients with moderate Alzheimer's disease. J. Nutr. Health Aging 16, 472-477. doi: 10. 1007/s12603-012-0058-4

Toledo, J. B., Toledo, E., Weiner, M. W., Jack, C. R., Jr., Jagust, W., Lee, V. M., et al. (2012). Cardiovascular risk factors, cortisol and amyloid- $\beta$ deposition in Alzheimer's disease neuroimaging initiative. Alzheimers Dement. 8, 483-489. doi: 10.1016/j.jalz.2011.08.008

Tritsch, N. X., and Sabatini, B. L. (2012). Dopaminergic modulation of synaptic transmission in cortex and striatum. Neuron 76, 33-50. doi: 10.1016/j.neuron. 2012.09.023

Ueki, K., Kondo, T., and Kahn, C. R. (2004). Suppressor of cytokine signaling 1 (SOCS-1) and SOCS-3 cause insulin resistance through inhibition of tyrosine phosphorylation of insulin receptor substrate proteins by discrete mechanisms. Mol. Cell. Biol. 24, 5434-5446. doi: 10.1128/mcb.24.12.5434-5446.2004

Umhau, J. C., Petrulis, S. G., Diaz, R., Rawlings, R., and George, D. T. (2003). Blood glucose is correlated with cerebrospinal fluid neurotransmitter metabolites. Neuroendocrinology 78, 339-343. doi: 10.1159/000074887

Vagelatos, N. T., and Eslick, G. D. (2013). Type 2 diabetes as a risk factor for Alzheimer's disease: the confounders, interactions and neuropathology associated with this relationship. Epidemiol. Rev. 35, 152-160. doi: 10. 1093/epirev/mxs012

van der Plasse, G., van Zessen, R., Luijendijk, M. C., Erkan, H., Stuber, G. D., Ramakers, G. M., et al. (2015). Modulation of cue-induced firing of ventral tegmental area dopamine neurons by leptin and ghrelin. Int. J. Obes. 39, 1742-1749. doi: 10.1038/ijo.2015.131

van Zessen, R., van der Plasse, G., and Adan, R. A. (2012). Contribution of the mesolimbic dopamine system in mediating the effects of leptin and ghrelin on feeding. Proc. Nutr. Soc. 71, 435-445. doi: 10.1017/s00296651120 00614
Velloso, L. A., Folli, F., and Saad, M. J. (2015). TLR4 at the crossroads of nutrients, gut microbiota and metabolic inflammation. Endocr. Rev. 36, 245-271. doi: 10. 1210/er.2014-1100

Vieira, J. R., Elkind, M. S., Moon, Y. P., Rundek, T., Boden-Albala, B., Paik, M. C., et al. (2011). The metabolic syndrome and cognitive performance: the Northern Manhattan study. Neuroepidemiology 37, 153-159. doi: 10.1159/0003 32208

Villar-Cheda, B., Rodríguez-Pallares, J., Valenzuela, R., Muñoz, A., Guerra, M. J., Baltatu, O. C., et al. (2010). Nigral and striatal regulation of angiotensin receptor expression by dopamine and angiotensin in rodents: implications for progression of Parkinson's disease. Eur. J. Neurosci. 32, 1695-1706. doi: 10. $1111 / \mathrm{j} .1460-9568.2010 .07448 . \mathrm{x}$

Volkow, N. D., Fowler, J. S., Wang, G. J., Baler, R., and Telang, F. (2009). Imaging dopamine's role in drug abuse and addiction. Neuropharmacology 56, 3-8. doi: 10.1016/j.neuropharm.2008.05.022

Wang, D., Li, Y., Lee, S. G., Wang, L., Fan, J., Zhang, G., et al. (2011). Ethnic differences in body composition and obesity related risk factors: study in Chinese and white males living in China. PLoS One 6:e19835. doi: 10. 1371/journal.pone.0019835

Wang, L., Yang, H. J., Xia, Y. Y., and Feng, Z. W. (2010). Insulin-like growth factor 1 protects human neuroblastoma cells SH-EP1 against $\mathrm{MPP}^{+}$-induced apoptosis by AKT/GSK-3beta/JNK signaling. Apoptosis 15, 1470-1479. doi: 10. 1007/s10495-010-0547-z

Wang, L., Zhai, Y. Q., Xu, L. L., Qiao, C., Sun, X. L., Ding, J. H., et al. (2014). Metabolic inflammation exacerbates dopaminergic neuronal degeneration in response to acute MPTP challenge in type 2 diabetes mice. Exp. Neurol. 251, 22-29. doi: 10.1016/j.expneurol.2013.11.001

Wei, Y., Williams, J. M., Dipace, C., Sung, U., Javitch, J. A., Galli, A., et al. (2007). Dopamine transporter activity mediates amphetamine-induced inhibition of Akt through a $\mathrm{Ca}^{2+} /$ calmodulin-dependent kinase II-dependent mechanism. Mol. Pharmacol. 71, 835-842. doi: 10.1124/mol.106.026351

Wild, S., Roglic, G., Green, A., Sicree, R., and King, H. (2004). Global prevalence of diabetes: estimates for the year 2000 and projections for 2030. Diabetes Care 27, 1047-1053. doi: 10.2337/diacare.27.5.1047

Williams, J. M., Owens, W. A., Turner, G. H., Saunders, C., Dipace, C., Blakely, R. D., et al. (2007). Hypoinsulinemia regulates amphetamine-induced reverse transport of dopamine. PLoS Biol. 5:e274. doi: 10.1371/journal.pbio. 0050274

Xu, B. Q., Yang, P., and Zhang, Y. Q. (2015). Hypoglycemic activities of lyophilized powder of Gynura divaricata by improving antioxidant potential and insulin signaling in type 2 diabetic mice. Food Nutr. Res. 59:29652. doi: 10.3402/fnr. v59.29652

Yacoubian, T. A., and Standaert, D. G. (2009). Targets for neuroprotection in Parkinson's disease. Biochim. Biophys. Acta 1792, 676-687. doi: 10.1016/j. bbadis.2008.09.009

Yoon, S. Y., and Oh, Y. J. (2015). Glucose levels in culture medium determine cell death mode in $\mathrm{MPP}^{+}$-treated dopaminergic neuronal cells. Exp. Neurobiol. 24, 197-205. doi: 10.5607/en.2015.24.3.197

Zawada, W. M., Kirschman, D. L., Cohen, J. J., Heidenreich, K. A., and Freed, C. R. (1996). Growth factors rescue embryonic dopamine neurons from programmed cell death. Exp. Neurol. 140, 60-67. doi: 10.1006/exnr. 1996.0115

Zeki Al Hazzouri, A., Stone, K. L., Haan, M. N., and Yaffe, K. (2013). Leptin, mild cognitive impairment and dementia among elderly women. J. Gerontol. A Biol. Sci. Med. Sci. 68, 175-180. doi: 10.1093/gerona/gls155

Zeng, C., Liu, Y., Wang, Z., He, D., Huang, L., Yu, P., et al. (2006). Activation of D3 dopamine receptor decreases angiotensin II type 1 receptor expression in rat renal proximal tubule cells. Circ. Res. 99, 494-500. doi: 10.1161/01.res. 0000240500.96746.ec

Zesiewicz, T. A., Strom, J. A., Borenstein, A. R., Hauser, R. A., Cimino, C. R., Fontanet, H. L., et al. (2004). Heart failure in parkinson's disease: analysis of the united states medicare current beneficiary survey. Parkinsonism Relat. Disord. 10, 417-420. doi: 10.1016/j.parkreldis.2004.04.001

Zhang, W., Phillips, K., Wielgus, A. R., Liu, J., Albertini, A., Zucca, F. A., et al. (2011). Neuromelanin activates microglia and induces degeneration of dopaminergic neurons: implications for progression of Parkinson's disease. Neurotox. Res. 19, 63-72. doi: 10.1007/s12640-009$9140-\mathrm{z}$ 
Ziemssen, T., and Reichmann, H. (2007). Non-motor dysfunction in Parkinson's disease. Parkinsonism Relat. Disord. 13, 323-332. doi: 10.1016/j.parkreldis. 2006.12.014

Ziemssen, T., and Reichmann, H. (2010). Cardiovascular autonomic dysfunction in Parkinson's disease. J. Neurol. Sci. 289, 74-80. doi: 10.1016/j.jns.2009.08.031

Zlokovic, B. V. (2011). Neurovascular pathways to neurodegeneration in Alzheimer's disease and other disorders. Nat. Rev. Neurosci. 12, 723-738. doi: 10.1038/nrn3114

Zweig, R. M., Jankel, W. R., Hedreen, J. C., Mayeux, R., and Price, D. L. (1989). The pedunculopontine nucleus in Parkinson's disease. Ann. Neurol. 26, 41-46. doi: 10.1002/ana.410260106
Conflict of Interest Statement: The authors declare that the research was conducted in the absence of any commercial or financial relationships that could be construed as a potential conflict of interest.

Copyright (c) 2016 Song and Kim. This is an open-access article distributed under the terms of the Creative Commons Attribution License (CC BY). The use, distribution and reproduction in other forums is permitted, provided the original author(s) or licensor are credited and that the original publication in this journal is cited, in accordance with accepted academic practice. No use distribution or reproduction is permitted which does not comply with these terms. 